DOI: 10.22630/EIOGZ.2014.107.24

Zeszyty Naukowe Szkoły Głównej Gospodarstwa Wiejskiego

Ekonomika i Organizacja Gospodarki Żywnościowej nr 107, 2014: 47-56

Magdalena D. Kowalewska

Katedra Ekonomiki i Organizacji Przedsiębiorstw

Szkoła Główna Gospodarstwa Wiejskiego w Warszawie

\title{
Kapitał ludzki jako źródło konkurencyjności państw członkowskich Unii Europejskiej
}

\section{Wstęp}

Powszechnie ekonomiści i eksperci uważają, że poziom konkurencyjności krajów, regionów czy miast ma kluczowe znaczenie w ocenie ich ekonomicznego rozwoju [Łaźniewska, Chmielewski 2012, s. 13]. Źródła przewagi konkurencyjnej regionu można lokalizować wewnątrz regionu, a także w jego mikroi makrootoczeniu [Grad 2009, s. 272].

Do czynników konkurencyjności w ujęciu makroekonomicznym zalicza się: potencjał demograficzny, kapitał ludzki, rynek pracy, innowacyjność, umiędzynarodowienie gospodarki, infrastrukturę techniczną i społeczną, politykę państwa, a także położenie geograficzne. Kapitał ludzki, jako jedno z podstawowych źródeł konkurencyjności, odgrywa coraz większą rolę w kontekście upowszechniania się gospodarki opartej na wiedzy [Klamut 2008, s. 50]. Strategia lizbońska zakłada, że wzrost zatrudnienia poprzez rozwój kapitału ludzkiego powinien przyczyniać się do lepszego wykorzystania zasobów pracy, a tym samym wzrostu konkurencyjności gospodarki. Problematyka kapitału ludzkiego dodatkowo staje się niezwykle istotna w kontekście starzejącego się społeczeństwa Unii Europejskiej.

\section{Cel i metody}

Celem artykułu jest przybliżenie istoty konkurencyjności i kapitału ludzkiego w ujęciu makroekonomicznym, a także przedstawienie kapitału ludzkiego jako źródła konkurencyjności państw członkowskich Unii Europejskiej. Kapitał ludz- 
ki został scharakteryzowany w ujęciu wąskim poprzez poziom wykształcenia mieszkańców poszczególnych państw w grupie wiekowej 25-64 lat oraz w ujęciu szerokim za pomocą syntetycznego wskaźnika kapitału ludzkiego. Do budowy wskaźnika kapitału ludzkiego w krajach Unii Europejskiej przyjęto następujące zmienne:

$x_{1}$ - udział osób z wykształceniem wyższym w grupie wiekowej 15-64 lat,

$x_{2}$ - udział osób aktywnych zawodowo w grupie wiekowej 15-64 lat,

$x_{3}$ - wskaźnik zatrudnienia w grupie wiekowej 15-64 lat,

$x_{4}$ - udział osób samozatrudnionych, w ogóle osób aktywnych zawodowo,

$x_{5}$ - wskaźnik lat zdrowego życia (HLY),

$x_{6}-$ saldo migracji.

Wszystkie zmienne zostały uznane za stymulanty. Zestaw wskaźników został wybrany na podstawie literatury przedmiotu, uwzględniając kryterium merytoryczne, statystyczne, a także dostępność danych.

Wybrane cechy znormalizowano za pomocą procesu unitaryzacji, wykorzystując następującą formułę:

$$
x_{i j}=\frac{x_{i j}-\min _{i} x_{i j}}{\max _{i} x_{i j}-\min _{i} x_{i j}}
$$

Wskaźnik syntetyczny został wyznaczony metodą bezwzorcową, polegająca na uśrednieniu znormalizowanych wartości cech prostych, według wzoru:

$$
s_{i}=\frac{1}{p} \sum_{j=1}^{p} x_{i j}
$$

Na podstawie wyznaczonych wskaźników kapitału ludzkiego kraje zostały podzielone na trzy klasy: klasa 1 - wysoki poziom kapitału ludzkiego, klasa 2 - średni poziom kapitału ludzkiego i klasa 3 - niski poziom kapitału ludzkiego. Przedziały klasowe zostały wyznaczone za pomocą wzorów:

- klasa 1 (wysoki poziom) $x_{i}=\left[\max _{i} x_{i}-\mathrm{h} ; \max _{i} x_{i}\right]$,

- klasa 2 (średni poziom) $x_{i}=\left[\max _{i} x_{i}-2 \mathrm{~h} ; \max _{i} x_{i}-\mathrm{h}\right]$,

- klasa 3 (niski poziom) $x_{i}=\left[\max _{i} x_{i} ; \max _{i} x_{i}-2 \mathrm{~h}\right]$,

Materiał empiryczny pochodził z danych Eurostatu za 2012 rok, a także krajowej i zagranicznej literatury przedmiotu. 


\section{Konkurencyjność w ujęciu teoretycznym}

Pojęcie konkurencyjności jest często stosowane w teorii i metodologii badań, aczkolwiek jest słowem wieloznacznym i wieloaspektowym, czego konsekwencją jest duża liczba definicji związanych z różnym rozumieniem jej źródeł oraz zakresu [Szwacka-Mokrzycka 2013, s. 77]. Szeroką definicję konkurencyjności zaproponowano na Światowym Forum Ekonomicznym w Lozannie w 1994 roku, gdzie określono ją jako „zdolność kraju lub przedsiębiorstwa do tworzenia większego bogactwa niż konkurenci na rynku światowym"1. W wielu podejściach do konkurencyjności nie wskazuje się podmiotu konkurowania (może nim być zarówno kraj, region, jak i przedsiębiorstwo) oraz traktuje się opisywane zjawisko w sposób względny [Filip, Sowa 2008, s. 62]. Przykładem tego podejścia jest definicja OECD, w świetle której „konkurencyjność oznacza zarówno zdolność firm, przemysłów, regionów, narodów lub ponadnarodowych ugrupowań do sprostania międzynarodowej konkurencji, jak i do zapewnienia relatywnie wysokiej stopy zwrotu od zastosowanych czynników produkcji i relatywnie wysokiego zatrudnienia na trwałych podstawach" [Stankiewicz 2005, s. 36]. Klasik [2001, s. 45] zauważa, że międzynarodowa konkurencyjność regionalna to zdolność regionu do wytwarzania dóbr i usług znajdujących odbiorców na rynkach międzynarodowych, w warunkach silnej konkurencji ze strony innych regionów.

Komisja Europejska definiuje konkurencyjność jako zdolność do wytwarzania dóbr i usług zdających egzamin na międzynarodowym rynku, przy jednoczesnym zachowaniu trwałego, wysokiego dochodu [Strzelecki 2010, s. 11]. Według definicji zaproponowanej przez Światowe Forum Ekonomiczne, konkurencyjność kraju jest to zdolność do trwałego, wysokiego tempa wzrostu PKB per capita. Fagerberg i inni [2004, s. 2] zauważają, że pojęcie konkurencyjności w ujęciu makroekonomicznym odnosi się zarówno do dobrobytu mieszkańców danego kraju, jak i jego pozycji w handlu zagranicznym.

\section{Istota i pomiar kapitał ludzkiego w ujęciu makroekonomicznym}

Znaczenie kapitału ludzkiego we wzroście gospodarczym zostało uchwycone w licznych modelach wzrostu gospodarczego. W neoklasycznym modelu wzrostu Mankiewa-Romera-Weila, będącym rozszerzeniem modelu Solowa, zakłada się, że gospodarka dąży do trwałego wzrostu, który zależy od inwestycji

\footnotetext{
${ }^{1}$ The World Competitiveness Report 1994, World Economic Forum, Lausanne 1994.
} 
w kapitał rzeczowy i ludzki, stóp deprecjacji tych obu kapitałów, stopy egzogenicznego postępu technicznego w sensie Harroda oraz stopy wzrostu populacji. W opozycji do modelu neoklasycznego powstały teorie wzrostu endogenicznego. Wśród nich najpopularniejsze są modele Lucasa i Romera. Model Lucasa zakłada, że dzięki istnieniu efektów zewnętrznych akumulacji kapitału ludzkiego możliwe jest trwałe podniesienie długookresowej stopy wzrostu gospodarczego. Z kolei w modelu Romera podkreśla się znaczenie zmian technologicznych, które są zachętą do akumulacji kapitału, dzięki czemu wpływają na wzrost produktu na pracującego [Roszkowska 2013, s. 73, 85-86].

Zgodnie z teorią wzrostu endogenicznego, najważniejszym stymulantem konkurencyjności kraju jest przyciaganie oraz akumulacja wykwalifikowanego i dobrze wyedukowanego kapitału ludzkiego. Wysoko wykwalifikowany kapitał ludzki sprzyja innowacyjności, przedsiębiorczości, kreowaniu i transferowi wiedzy oraz ma wpływ na postęp technologiczny. Kapitał ludzki jest jednym z podstawowych źródeł konkurencyjności gospodarki opartej na wiedzy. Wpływają na to między innymi takie jego cechy, jak: mniejsza mobilność w porównaniu na przykład z kapitałem finansowym oraz długi cykl inwestycyjny związany z poprawą jego jakości [Łaźniewska, Nowak 2012, s. 64].

Nie ma jednej, spójnej grupy wskaźników, które wykorzystuje się do pomiaru kapitału ludzkiego i w literaturze można znaleźć liczne propozycje prezentujące różne podejścia badawcze. Najpopularniejszą metodą pomiaru kapitału ludzkiego jest prezentowanie poziomu wykształcenia i miar pokrewnych. W tym celu stosuje się między innymi współczynnik piśmiennictwa oraz współczynnik skolaryzacji. Łaźniewska i Nowak [2012, s. 64] definiują jakość kapitału ludzkiego jako zasób wiedzy, umiejętności, zdrowia i inicjatywy, którą można ocenić poprzez potencjał demograficzy, poziom wiedzy funkcjonalnej, stan zdrowia, mobilność przestrzenna, aktywność gospodarczą i społeczną. $W$ opracowaniu przyjęto właśnie tę definicję.

Mossakowska i Zawojska [2009, s. 7] do pomiaru kapitału ludzkiego proponują zestaw wskaźników charakteryzujących wykształcenie, aktywność zawodową, zatrudnienie, przedsiębiorczość, zdrowie i migracje.

\section{Poziom kapitału ludzkiego w krajach Unii Europejskiej}

Jednym z najpopularniejszych wskaźników wykorzystywanych do oceny kapitału ludzkiego w ujęciu makroekonomicznym jest charakterystyka poziomu wykształcenia. W opracowaniu przedstawiono poziom wykształcenia osób w wieku od 25 do 64 lat. Taki przedział wiekowy wydaje się być bardziej adekwatny w kontekście analiz ekonomicznych. Ponadto był to przedział najbardziej użyteczny spośród proponowanych przez Eurostat. 
Na rysunku 1 zaproponowano uproszczony podział poziomu wykształcenia, dzieląc je na: podstawowe, średnie i wyższe. Wynika to ze stosowanego przez Eurostat podziału, który umożliwia porównywanie wyników dla wszystkich krajów UE. Należy mieć jednak świadomość, że w przypadku Polski kategoria wykształcenie podstawowe obejmuje wykształcenie podstawowe, gimnazjalne i zasadnicze zawodowe, a kategoria wykształcenie średnie: wykształcenie średnie, ponadgimnazjalne i policealne.

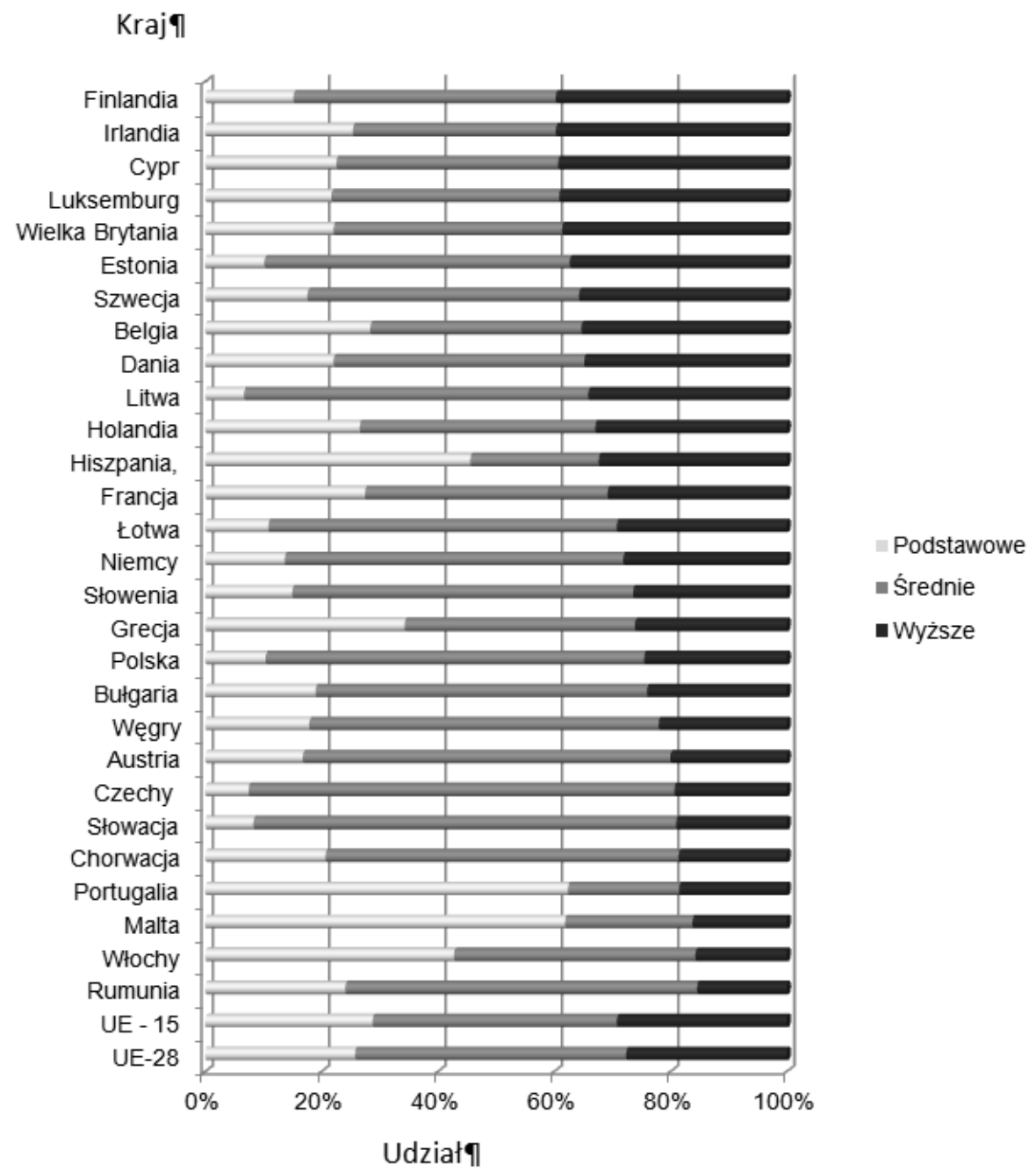

\section{Rysunek 1}

Poziom wykształcenia w grupie wiekowej 25-64 lata w krajach Unii Europejskiej w 2012 roku

Źródło: Opracowanie własne na podstawie Eurostatu. 
Średnio w całej Unii Europejskiej (UE-28) blisko jedna trzecia jej mieszkańców ma wykształcenie wyższe, a blisko połowa wykształcenie średnie. Najniższy odsetek osób z wykształceniem wyższym posiadają: Rumunia, Włochy, Malta, Portugalia i Chorwacja, najwyższy zaś: Finlandia, Irlandia, Cypr, Luksemburg i Wielka Brytania. Polska w 2012 roku znalazła się na trzynastej pozycji.

W celu przedstawienia poziomu kapitału ludzkiego za pomocą syntetycznego wskaźnika obliczono wskaźnik kapitału ludzkiego (WKL) dla wszystkich krajów członkowskich. Następnie stworzono ranking wszystkich państw i wyznaczono trzy przedziały klasowe:

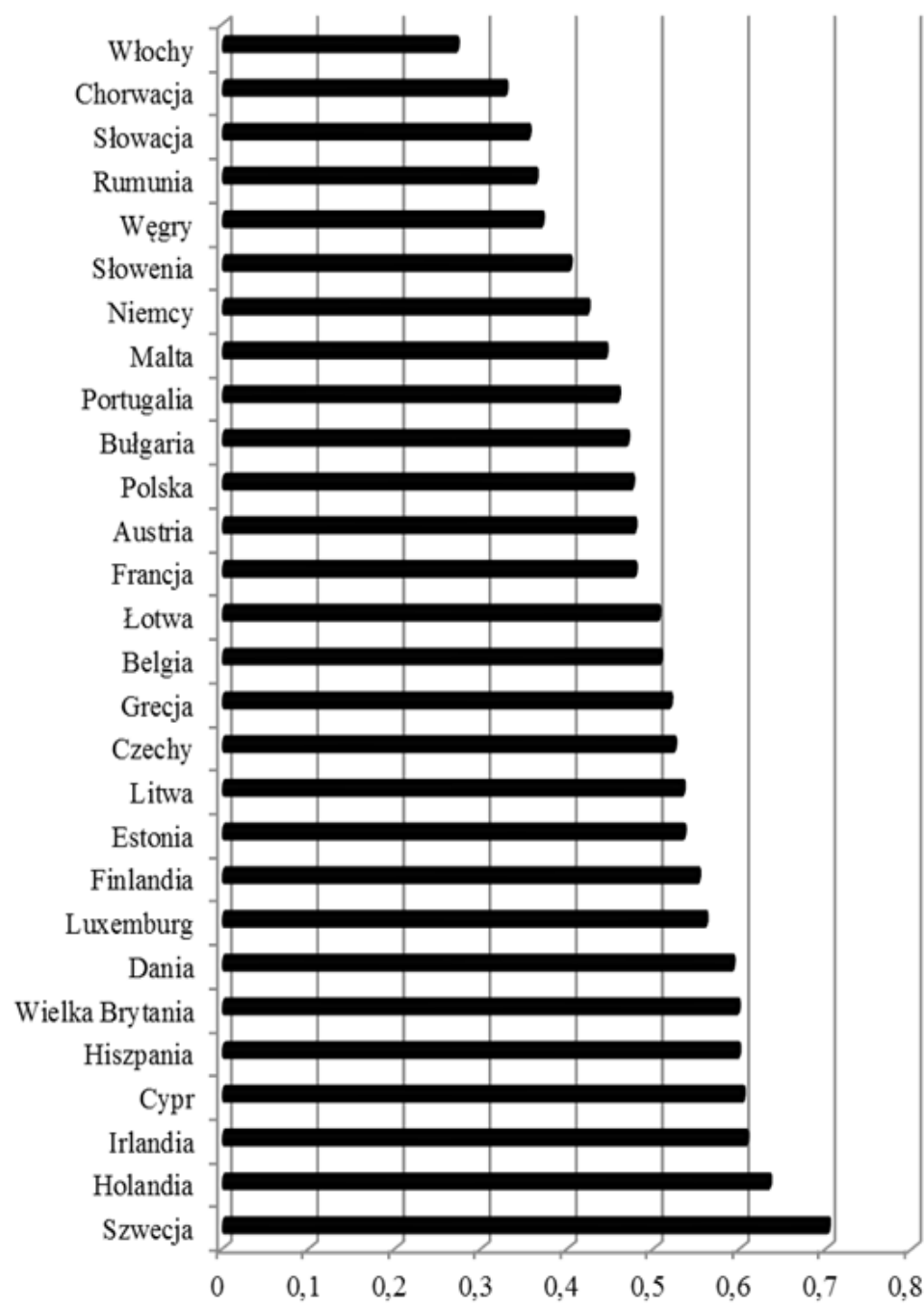

Rysunek 2

Poziom wskaźnika kapitału ludzkiego w krajach Unii Europejskiej w 2012 roku Źródło: Opracowanie własne. 
- klasa $1 \mathrm{WKL} \in(0,557 ; 0,701)$ - wysoki poziom,

- klasa 2 WKL $\in(0,413 ; 0,557)$ - średni poziom,

- klasa $3 \mathrm{WKL} \in(0,269 ; 0,413)$ - niski poziom.

Poszczególne państwa członkowskie przydzielono do jednej z klas (rys. 2). W klasie pierwszej znalazły się kraje o wysokim poziomie kapitału ludzkiego: Szwecja, Holandia, Irlandia, Cypr, Hiszpania, Wielka Brytania, Dania, Luksemburg i Finlandia. Do drugiej klasy zaliczono Estonię, Litwę, Czechy, Grecję, Belgię, Łotwę, Francję, Austrię, Polskę, Bułgarię, Portugalię, Maltę i Niemcy. Państwa o niskim poziomie kapitału ludzkiego zostały zaliczone do klasy 3, a wśród nich znalazły się: Słowenia, Wegry, Rumunia, Słowacja, Chorwacja i Włochy.

Uzyskane wyniki różnią się od wyników zaprezentowanych przez World Economic Forum w The Human Capital Report z 2013 roku, co może wynikać głównie z faktu, że we wspomnianym badaniu wykorzystano zdecydowanie więcej wskaźników cząstkowych, uwzględniając więcej zmiennych. Należy przy tym zaznaczyć, że różnice te dotyczą głównie pozycji rankingowych, a w mniejszym stopniu grupy, do jakiej dany kraj został zaliczony.

\section{Kapitał ludzki jako źródło konkurencyjności państw Unii Europejskiej}

Niejednoznaczność pojęcia „konkurencyjność” powoduje problemy związane z wyznaczeniem odpowiedniego wskaźnika, który będzie odzwierciedlał rzeczywistą pozycję konkurencyjną krajów i umożliwi ich porównanie. Siudek i Zawojska [2014, s. 103] uważają, że najlepszym rozwiązaniem w tym zakresie jest stosowanie wielowymiarowych wskaźników. Według Góreckiego i innych [2012, s. 72], najpopularniejszymi wskaźnikami, wykorzystywanymi do pomiaru konkurencyjności regionów i krajów, są: PKB per capita, wskaźnik produktywności, czy też terms od trade względnego kosztu jednostki pracy. Jak zauważają Podobnik i inni [2012, s. 1-2], bogatsze, o wyższym poziomie PKB per capita są bardziej konkurencyjne. W związku z powyższym w opracowaniu za pośrednią miarę konkurencyjności przyjęto PKB per capita mierzony w standardzie siły nabywczej.

W celu zbadania zależności pomiędzy poziomem kapitału ludzkiego a konkurencyjnością państw członkowskich Unii Europejskiej porównano wartość PKB per capita ze wskaźnikiem kapitału ludzkiego w badanych krajach. Ponadto obliczono współczynnik korelacji Pearsona, który wyniósł 0,41, co oznacza dodatnią, istotną współzależność pomiędzy badanymi zmiennymi. Następnie zbudowano macierz powiązań wskaźnika kapitału ludzkiego i PKB per capita (tab. 1). Za państwa wysoko konkurencyjne uznano te, których PKB 
Tabela 1

Macierz powiązań pomiędzy wskaźnikiem kapitału ludzkiego a PKB per capita mierzonego w standardzie siły nabywczej w krajach UE w 2012 roku

\begin{tabular}{|l|r|l|c|}
\hline WKL & WhB per \\
capita & Wysoki & Średni & Niski \\
\hline Wysoki & $\begin{array}{r}\text { Szwecja, Holandia, } \\
\text { Irlandia, Wielka Brytania, } \\
\text { Dania, Luksemburg, } \\
\text { Finlandia }\end{array}$ & Cypr & Hiszpania \\
\hline Średni & $\begin{array}{r}\text { Belgia, Francja, Austria, } \\
\text { Niemcy }\end{array}$ & Czechy, Malta & $\begin{array}{c}\text { Estonia, Litwa, Grecja, } \\
\text { Łotwa, Polska, Bułgaria, } \\
\text { Portugalia }\end{array}$ \\
\hline Niski & Włochy & Słowenia & $\begin{array}{c}\text { Węgry, Rumunia, } \\
\text { Słowacja, Chorwacja }\end{array}$ \\
\hline
\end{tabular}

Źródło: Opracowanie własne.

per capita mierzone w standardzie siły nabywczej było wyższe niż średnia wartość dla wszystkich państw Unii Europejskiej, z kolei kraje, których PKB per capita było poniżej $80 \%$ średniej dla UE zostały zakwalifikowane do grupy krajów mało konkurencyjnych. Państwa, które znalazły się pomiędzy tymi wartościami zakwalifikowano do grupy średnio konkurencyjnych.

Wysokim poziomem zarówno wskaźnika kapitału ludzkiego, jak i PKB per capita charakteryzowały się: Szwecja, Holandia, Irlandia, Wielka Brytania, Dania, Luksemburg i Finlandia, a niską wartością obu tych cech: Węgry, Chorwacja, Rumunia i Słowacja. Polska znalazła się w grupie państw o niskiej pozycji konkurencyjnej i średnim poziomie kapitału ludzkiego, obok Łotwy, Litwy, Hiszpanii, Portugalii, Grecji, Estonii i Bułgarii. Krajem wyróżniającym się pod względem PKB per capita w 2012 roku był Luksemburg, który jednocześnie charakteryzował się wysokim poziomem wskaźnika kapitału ludzkiego.

\section{Podsumowanie i wnioski}

Kapitał ludzki jest istotnym źródłem konkurencyjności międzynarodowej. W gospodarce opartej na wiedzy wspieranie jego rozwoju powinno być jednym z najważniejszych elementów polityki regionalnej. W obliczu konieczności zmierzenia się z problemem starzejącego się społeczeństwa Unii Europejskie dbałość i troska o kapitał ludzki powinna stać się jednym z priorytetowych zadań wspólnej polityki. 
Z przeprowadzonych badań wynika, że Unia Europejska charakteryzuje się dużym zróżnicowaniem pod względem poziomu kapitału ludzkiego. Wszystkie kraje, które zostały zaliczone do klasy o najwyższym poziomie badanej cechy, z wyjątkiem Cypru i Hiszpanii, znalazły się również w grupie państw najbardziej rozwiniętych pod względem gospodarczym, co potwierdza tezę o pozytywnej współzależności. Trudno jest natomiast jednoznacznie określić, czy to kapitał ludzki wpływa na wyższy poziom PKB na mieszkańca, czy też odwrotnie - to wysokie PKB stymuluje rozwój tego kapitał. Jest to zagadnienie niezwykle ciekawe i z pewnością może stać się przyczynkiem do dalszych prac badawczych.

Należy podkreślić, że uzyskane rezultaty mają swoje ograniczenia. Wśród nich najważniejsze to dobór zmiennych wskaźnikowych oraz metoda budowy miernika syntetycznego. Zaprezentowane wyniki ujęto w sposób statyczny, dla jednego, wybranego roku, nie uwzględniając dynamiki badanego zjawiska. Ponadto analiza współzależności kapitału ludzkiego i konkurencyjności została przeprowadzona bez użycia zaawansowanych metod statystycznych.

\section{Literatura}

FILIP P., SOWA B., 2008: Konkurencja podatkowa jako efekt globalizacji gospodarki światowej, [w:] Najnowsze zmiany polskiego prawa prywatnego i publicznego a funkcjonowanie rynków finansowych, Wydawnictwo TNOiK O/Rzeszów, Rzeszów.

FAGERBERG J., KNELL M., SRHOLEC M., 2004: The Competitiveness of Nations: Economic Growth in the ECE Region, http://www.unece.org/fileadmin/DAM/ead/sem/ sem2004/papers/Fagerberg.pdf (data dostępu: 25.07.2014)

GÓRECKI T., ŁAŹNIEWSKA E., CHMIELEWSKI R., 2012: Problemy metodologiczne ludowy wskaźników i indeksów konkurencyjności, [w:] Konkurencyjność regionalna. Koncepcja-strategie-przykłady, red. nauk. E. Łaźniewska, M. Gorynia, Wydawnictwo Naukowe PWN, Warszawa.

GRAD B., 2009: Ksztaltowanie konkurencyjności regionu - nowego atrybutu przestrzeni gospodarczej Unii Europejskiej w świetle uwarunkowań polityki innowacyjnej perspektywy finansowej UE dla Polski na lata 2007-2013, Zeszyty Naukowe SGGW, Polityki Europejskie, Finansów i Marketingu, Wydawnictwo SGGW, Warszawa, nr 1(50), s. 272.

KLAMUT M., 2008: Konkurencyjność gospodarki regionalnej i lokalnej, [w:] Gospodarka regionalna i lokalna, Wydawnictwo Naukowe PWN, Warszawa.

KLASIK A., 2001: Konkurencyjność województwa ślaskiego na tle innych regionów. Ujęcie statyczne, [w:] Województwo ślaskie. Integracja, konkurencyjność, nowe inicjatywy, II Śląskie Forum Rozwoju Lokalnego i Regionalnego, AE i Górnośląska Wyższa Szkoła Przedsiębiorczości im. K. Goduli, Katowice.

Komisja Europejska, Sixth Perodic Report on the Social and Economic Situation and Development of the Regions of the the EU, Belgia 1999. 
Komisja Europejska: Edukacja w Europie: różne systemy kształcenia i szkolenia - wspólne cele do roku 2010. Program prac dotyczqcy przyszlych celów systemów edukacji, Luksemburg 2002.

ŁAŹNIEWSKA E., CHMIELEWSKI R., 2012: Konkurencyjność regionalna jako termin ekonomii, [w:] Konkurencyjność regionalna. Koncepcje - strategie - przykłady, red. nauk. E. Łaźniewska, M. Gorynia, Wydawnictwo Naukowe PWN, Warszawa, s. 13.

ŁAŹNIEWSKA E., NOWAK M., 2012: Źródła regionalnej konkurencyjności, [w:] Konkurencyjność regionalna. Koncepcje - strategie - przykłady, red. nauk. E. Łaźniewska, M. Gorynia, Wydawnictwo Naukowe PWN, Warszawa, s. 64.

MOSSAKOWSKA E., ZAWOJSKA A., 2009: Rozwój gospodarczy a kapitał ludzki na terenach wiejskich $w$ Polsce, Zeszyty Naukowe SGGW - Ekonomika i Organizacja Gospodarki Żywnościowej, Wydawnictwo SGGW, Warszawa, nr 79, s. 7.

PODOBNIK B., HORVATIĆ D., KENETT D., STANLEY H., 2012: The competitiveness versus the wealth of a country, Scientific Reports 2, nr 678, s. 1-2.

ROSZKOWSKA M., 2013: Kapitał ludzkie a wzrost gospodarczy, Wydawnictwo Uniwersytetu Łódzkiego, Łódź.

SIUDEK T., ZAWOJSKA A., 2014: Competitiveness in the economic concepts, theories and empirical research, Acta Oeconomia 13(1), Warszawa.

STRZELECKI Z. (red.), 2010: Konkurencyjność województwa mazowieckiego na tle Polski i Unii Europejskiej, Analizy i Studia, Zeszyt 5 (25), Warszawa.

STANKIEWICZ M.J., 2005: Konkurencyjność przedsiębiorstwa, [w:] Budowanie konkurencyjności przedsiębiorstwa w warunkach globalizacji, Wydawnictwo „Dom Organizatora", Toruń.

SZWACKA-MOKRZYCKA J., 2013: Tendencje rozwojowe popytu i podaży żywności $w$ Polsce, Wydawnictwo SGGW, Warszawa.

The Human Capital Report, World Economic Forum, 2013, http://www3.weforum.org/docs/ WEF_HumanCapitalReport_2013.pdf (data dostępu: 19.07.2014).

The World Competitiveness Report 1994, World Economic Forum, Lausanne 1994.

\section{Human capital as a source of competitiveness of European Union member states}

\section{Abstract}

The purpose of the article was to present the essence of competitiveness and human capital from the macroeconomic perspective, as well as to present human capital as a source of competitiveness of the European Union member states. In order to assess the human capital of the member states, the level of education of residents, as well as calculated synthetic indicator of human capital were analysed. In addition, relationship between the level of the indicator of human capital and competitiveness of the member states, measured by GDP per capita was examined. 